\title{
1998 Annual Report - Environmental Restoration Division
}

by

L. B. Davis

Westinghouse Savannah River Company

Savannah River Site

Aiken, South Carolina 29808

M. Cosper

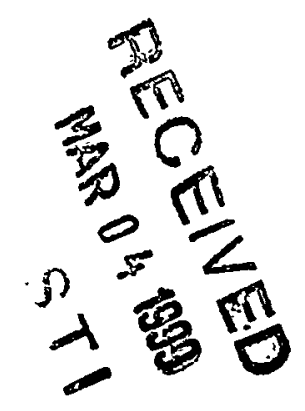

This paper was prepared in connection with work done under the above contract number with the U.S.

Department of Energy. By acceptance of this paper, the publisher and/or recipient acknowledges the U. S. Government's right to retain a nonexclusive, royalty-free license in and to any copyright covering this paper, along with the right to reproduce and to authorize others to reproduce all or part of the copyrighted paper. 


\section{DISCLAIMER}

This report was prepared as an account of work sponsored by an agency of the United States Government. Neither the United States Government nor any agency thereof, nor any of their employees, makes any warranty, express or implied, or assumes any legal liability or responsibility for the accuracy, completeness, or usefulness of any information, apparatus, product, or process disclosed, or represents that its use would not infringe privately owned rights. Reference herein to any specific commercial product, process, or service by trade name, trademark, manufacturer, or otherwise does not necessarily constitute or imply its endorsement, recommendation, or favoring by the United States Government or any agency thereof. The views and opinions of authors expressed herein do not necessarily state or reflect those of the United States Government or any agency thereof.

This report has been reproduced directly from the best available copy.

Available to DOE and DOE contractors from the Office of Scientific and Technical Information, P. O. Box 62, Oak Ridge, TN 37831; prices available from (423) 576-8401.

Available to the public from the National Technical Information Service, U. S. Department of Commerce, 5285 Port Royal Road, Springfield, VA 22161. 


\section{DISCLAIMER}

Portions of this document may be illegible in electronic image products. Images are produced from the best available original document. 
SAVANNAH RIVER SITE • Environmental Restoration Division
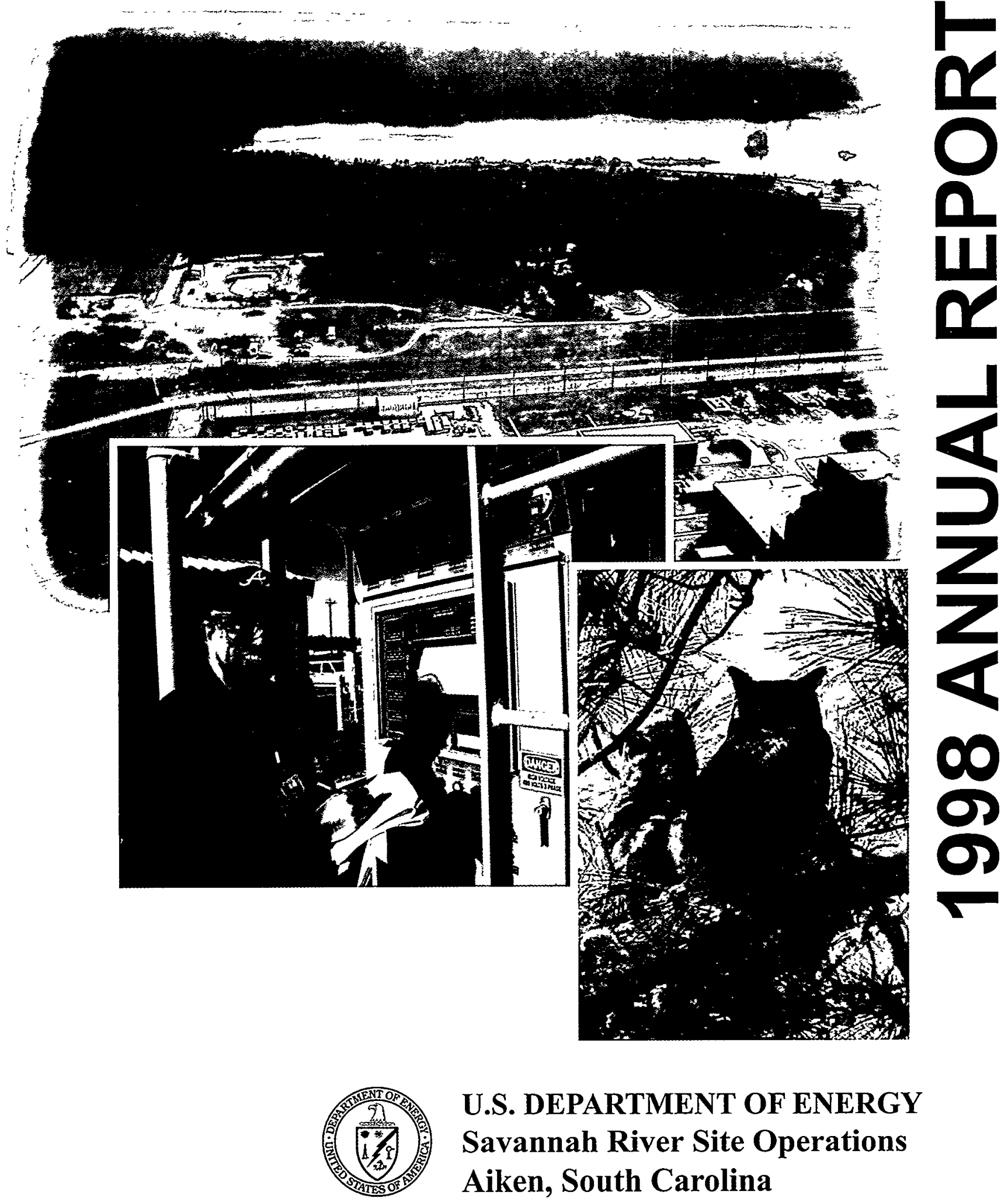

U.S. DEPARTMENT OF ENERGY Savannah River Site Operations Aiken, South Carolina 


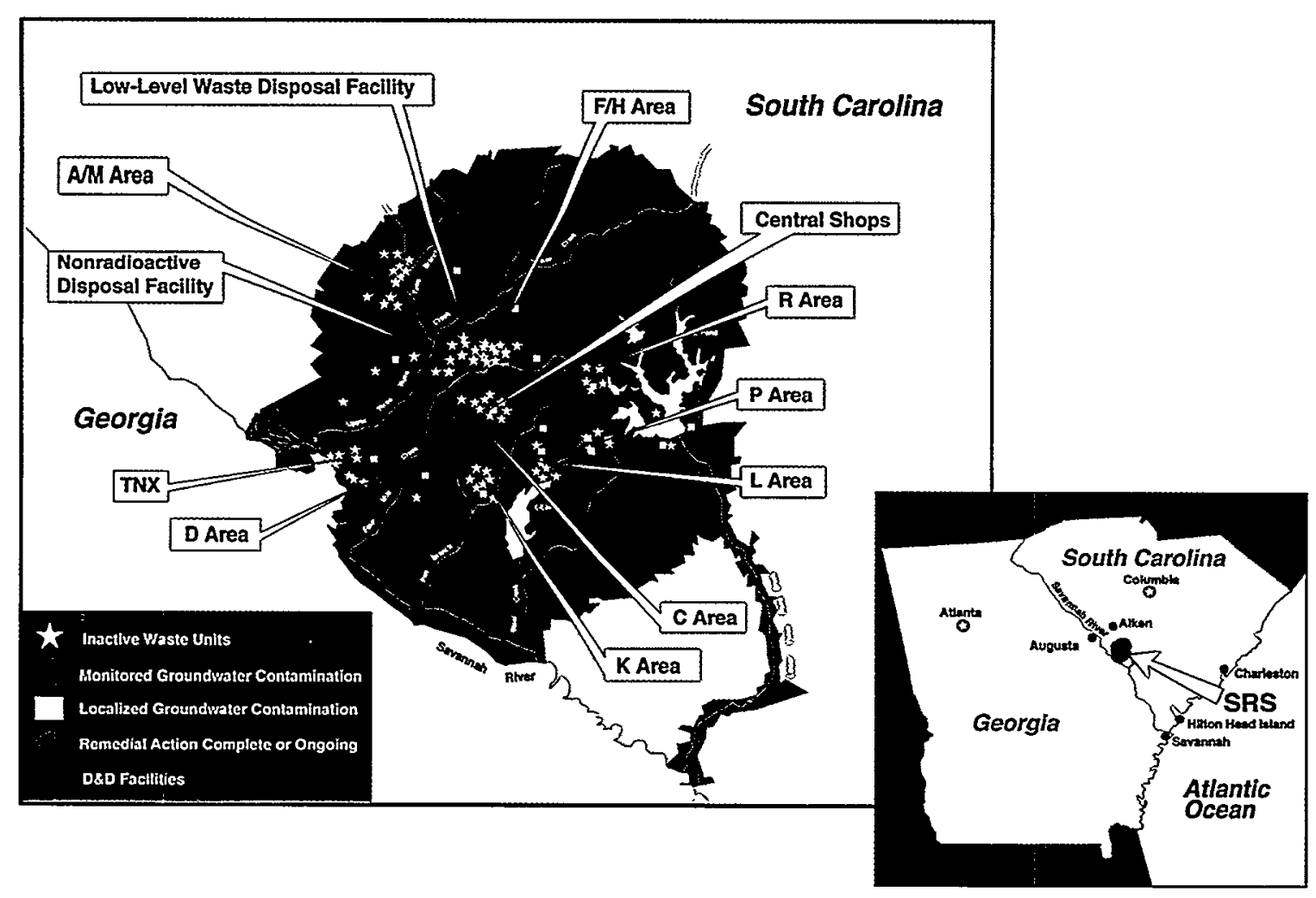

\section{SRS Environmental Restoration Program}

The Savannah River Site (SRS) is located on 300 square miles in central South Carolina bordering the Savannah River. The SRS Environmental Restoration Program was formed to clean up contamination that resulted from over 40 years of nuclear research and production to support our nation's defense.

Our Mission - Remediate waste sites and groundwater units to reduce risk to the environment for future land use and to demonstrate capabilities to attract and succeed in new missions.

Our Vision - Continuously exceed the needs and expectations of our customers and become recognized as best for environmental restoration through the application of innovative technologies, a strong commitment to teamwork, highly qualified personnel, and attention to continuous improvement.

\section{Principles:}

- Safety is our first priority

- People are our most important resource

- High Performance Teams are created and sustained

- Customer satisfaction is a continuous focus

- Project management systems are rigorously used

- Long-range strategic planning is valued

- Achieving excellence is a commitment 


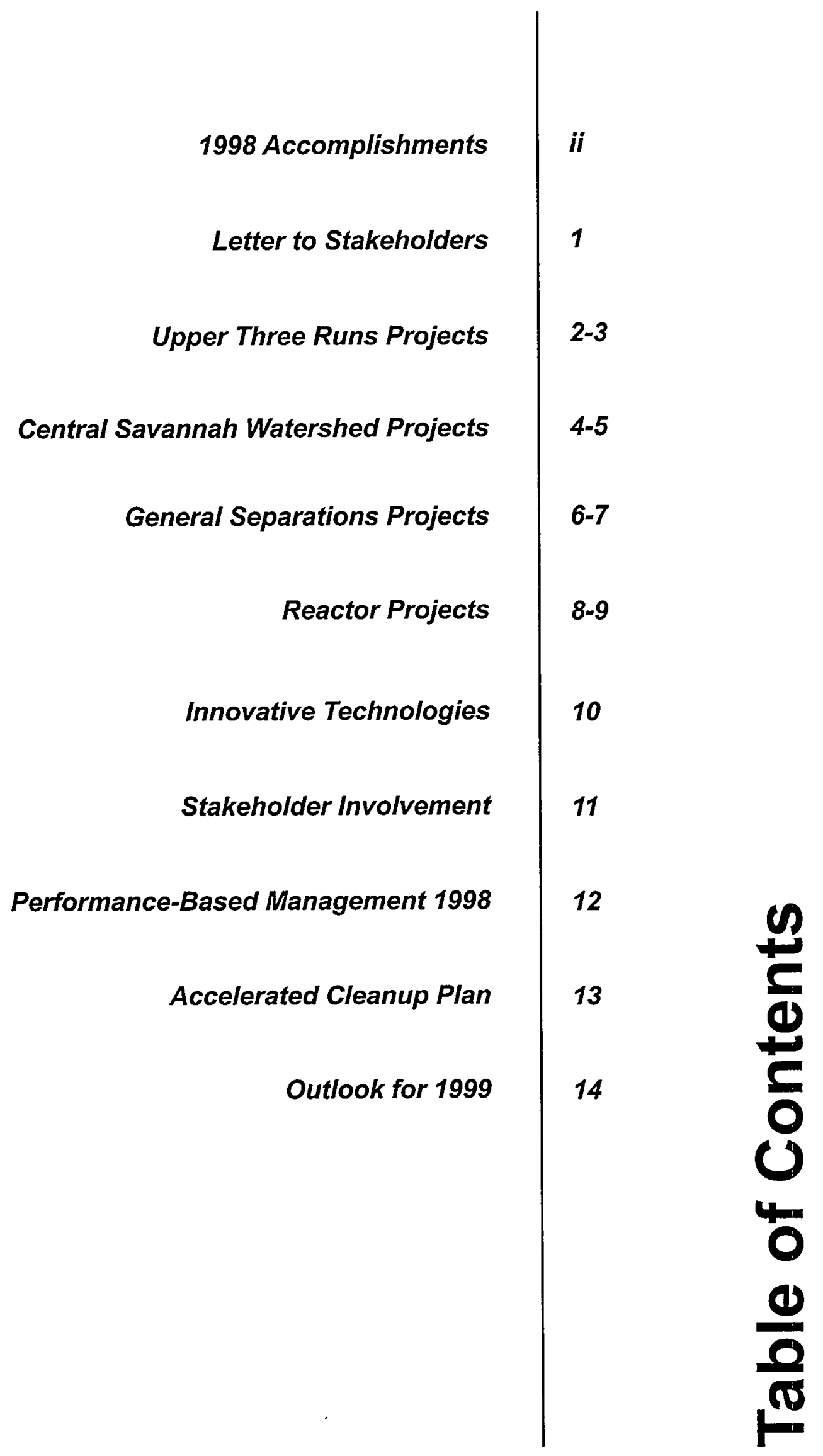


Savannah River Site

Environmental Restoration Division

\section{Environmental Restoration Noteworthy FY 98 Accomplishments}

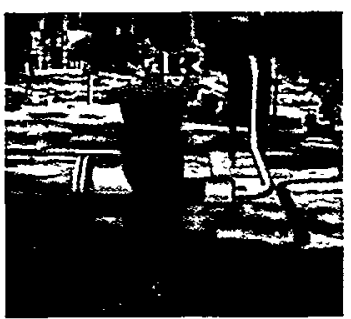

Upper Three Runs Projects

Installation of 12 recirculation wells

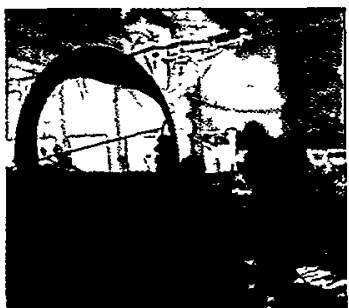

Central Savannah Watershed Projects

Removal of 6,000-gallon retention tank

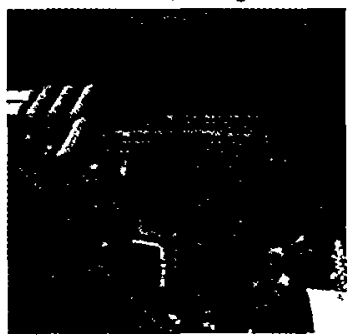

General Separations

Projects

Geosynthetic capping - 25 acres

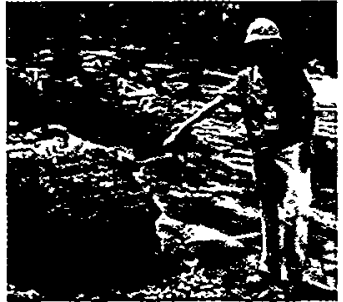

Reactor Projects

Over 13 thousand batteries removed

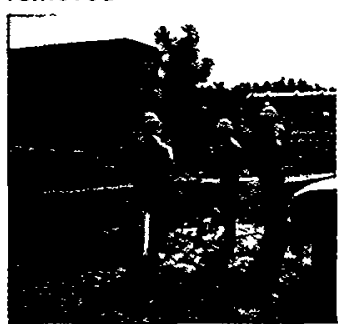

Innovative Technologies

Sharing information/supporting -Kings Bay Naval Base, GA
Environmental Restoration's accomplishments were significant in 1998. The division, including its support organizations, completed one year without a lost time accident. It also met 111 enforceable agreement milestones on time, with more than $80 \%$ ahead of schedule. Funds used to meet these milestones were effectively utilized and $\$ 9.63$ million in regulatory scope was added.

Twelve new, innovative technologies were deployed, enabling ER to achieve significant progress on major field remediation projects, including:

- Remediation of $\mathbf{2 5}$ acres of radioactive burial ground

- Removal of 1,300 batteries for recycling

- Removal and safe storage of a radioactive underground tank

- Extraction of 115,000 pounds of solvent

- Installation of 9 new recirculation wells and a second GeoSiphon Cell for additional removal of solvent

Final Records of Decision were made for 9 base unit sites. No Further Action decisions were made for 61 additional sites. 


\section{Letter to Stakeholders:}

A core value of the Savannah River Site is to respect and protect the environment. We personally recognize this as a site responsibility. This value is upheld by the important efforts of the Environmental Restoration Division to remediate soil and groundwater. Through a commitment to strategic goals and innovative thinking, ER has developed a premier program. Five focus areas drive ER: Safety, Technical Capability and Performance, Cost Effectiveness, Community and Regulatory Relationships, and Corporate Exchange.

Safety is clearly the number one priority. We plan our work, identify hazards, develop controls, conduct the work as planned, and learn from experience.

The technical capability and performance of the ER workforce ensures that program goals are achieved. We are focused on remediation of 477 identified waste sites. Over half of the waste sites and more than 300 of the 500 contaminated acres are completed or are in the remediation phase at this point in time. Six major groundwater systems are operating and more than three billion-gallons of groundwater have been cleaned to drinking water standards.

Cost effectiveness has ensured that all regulatory milestones and cleanup goals are met within the budget allocation. Deployment of innovative technologies has also saved money and sustained ER. In the last three years, 35 deployments of new and innovative technologies have driven success for the ER Program. Additionally, over $\$ 68 \mathrm{M}$ in documented cost efficiencies has been reinvested in the program in the last four years. That means that about $20 \%$ more work is accomplished each year for the original budget.

Community and regulatory relationships have been maintained through constant communication and responsive actions. Regulatory oversight is an integral part of our cleanup progress. Each year we accomplish about 100 regulatory milestones on time or ahead of schedule. Our Citizen's Advisory Board is involved early in strategic planning for the work we do.

SRS has hosted end users of environmental restoration technology from across the nation for an annual conference focusing on new and innovative technologies to save time and money. SRS is also leading the Program Area Integration Team on Environmental Restoration for the DOE Complex. We are proud of the role our program now plays as a national leader in environmental cleanup.
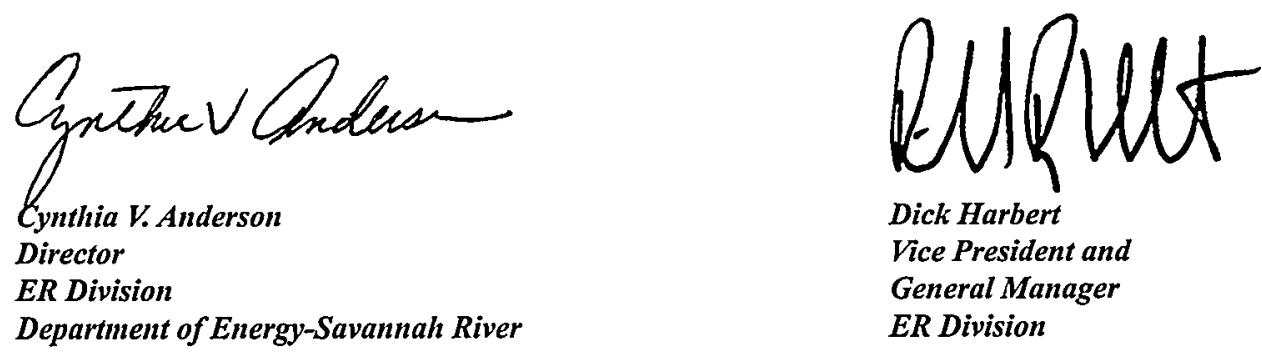

Westinghouse Savannah River Company 


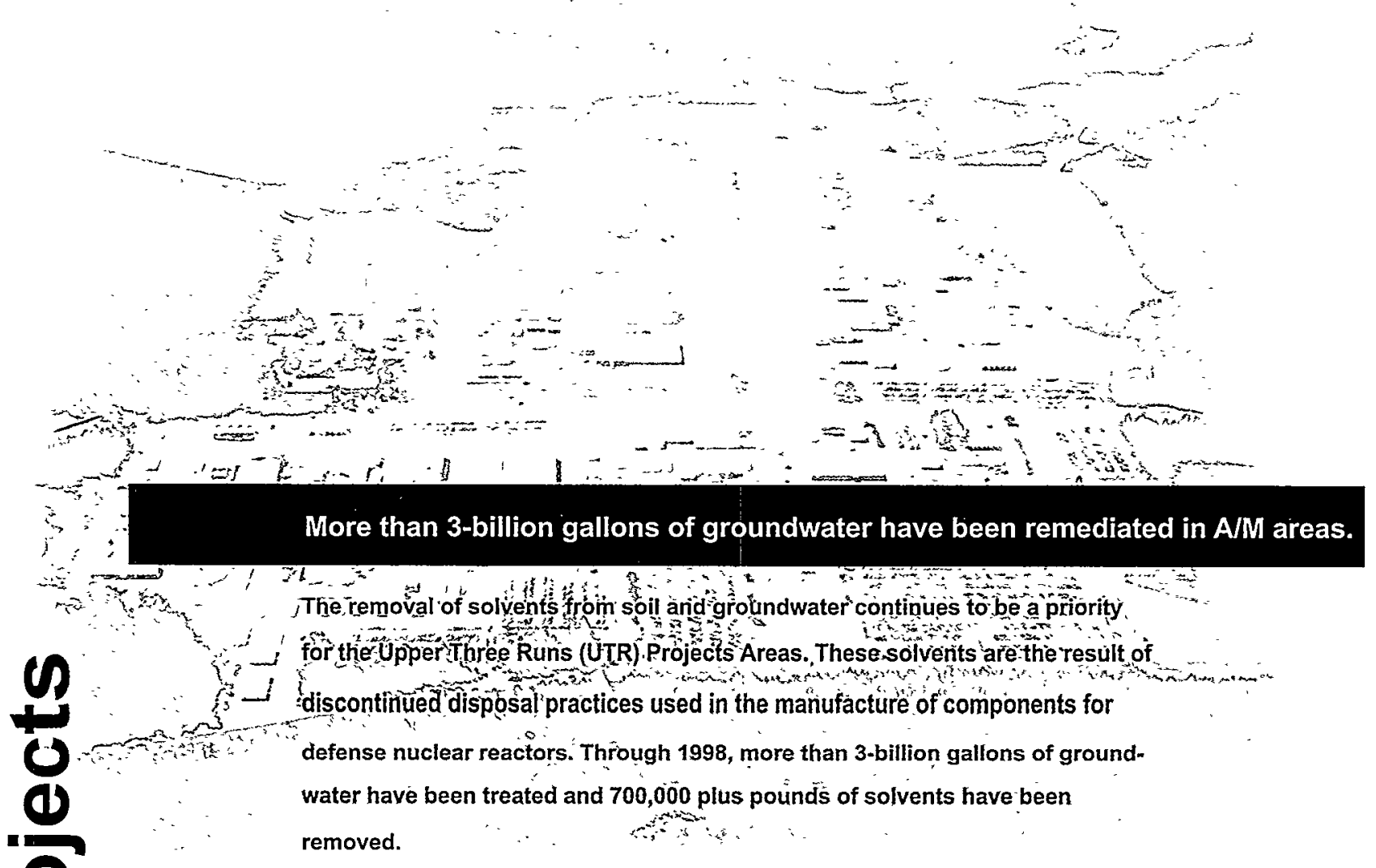

An emphasis in 1998 has been to increase efficiency of existing groundwater treatment systems and to deploy newer, more efficient cleanup technologies. In the UTR Project Areas, SRS successfully reduced hourly operating costs of existing treatment systems by 22 percent. The best measure of successful

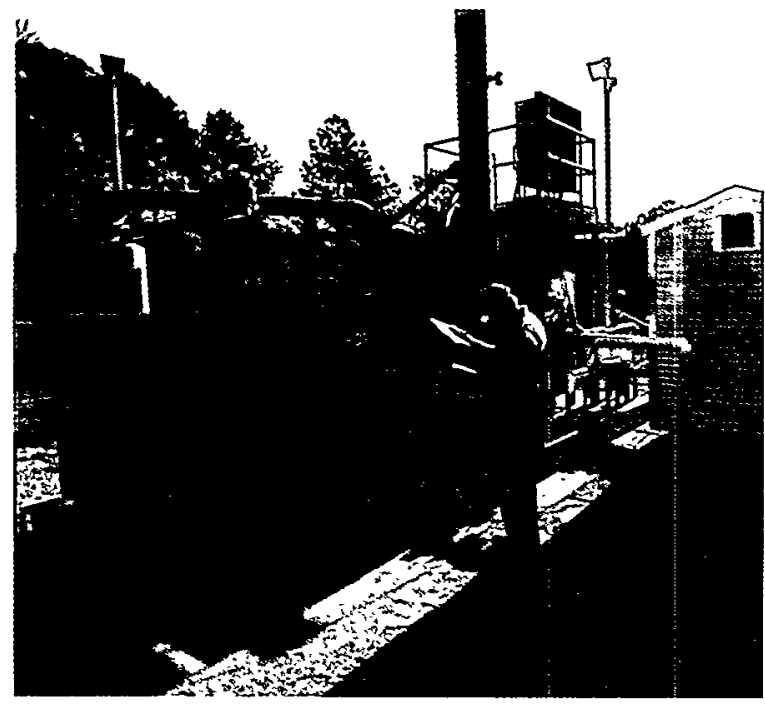

This $M$-Area soil vapor extraction unit is one of four now used to remove solvent contaminants before they reach the groundwater.

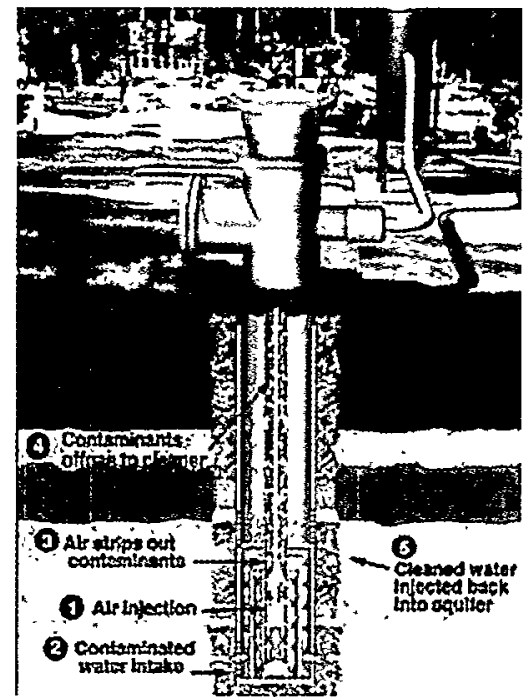

Multi-stage in-well aerator technology is being tested at Southem Sector and will be deployed at two other sites in the future. 
cleanup is that two of the six soil-vapor extraction units were shut down as sufficient cleanup was accomplished. This technology removes solvents from the soil above the water table through slotted well piping. Unit shutdown is the first step toward permanently deactivating aggressive soil-vapor extraction and switching to the passive BaroBall ${ }^{\mathrm{TM}}$ treatment method. This method is a low cost technology that has been highly effective at the site. Essentially, a small ball atop of a well pipe, the BaroBall ${ }^{\mathrm{TM}}$ allows solvents to be safely vented to the atmosphere but also guards against them being pushed back into the well.

Another accomplishment was completing the curtain of 12 recirculation wells in the Southern Sector. Focused on the most concentrated contour of the solvent plume, recirculation well technology performs in situ stripping of contaminants in the following manner. Air pumped down a center well travels upward in an outer well, lifting and stripping the contaminated groundwater. The stripped solvent is exhausted to the atmosphere while the cleaned water is returned to the aquifer. The groundwater in the affected well zone is cycled through the system several times, adding to cleanup efficiency. The cost of this remediation method is about half the cost of conventional above ground air strippers.

This year the team also accomplished additional work at the Nonradioactive Waste Disposal Facility (NRWDF) in B-Area. The landfill has been closed with a geosynthetic cap; however, the groundwater must be remediated. This year ER finished installation of the two longest horizontal wells in the United States used for environmental purposes. When associated infrastructure is completed in 1999, the wells will be an important part of a new bioremediation system that will deliver methane and other microbe-stimulating nutrients into contaminated groundwater. Once stimulated, the microbes will biodegrade solvent groundwater plumes.

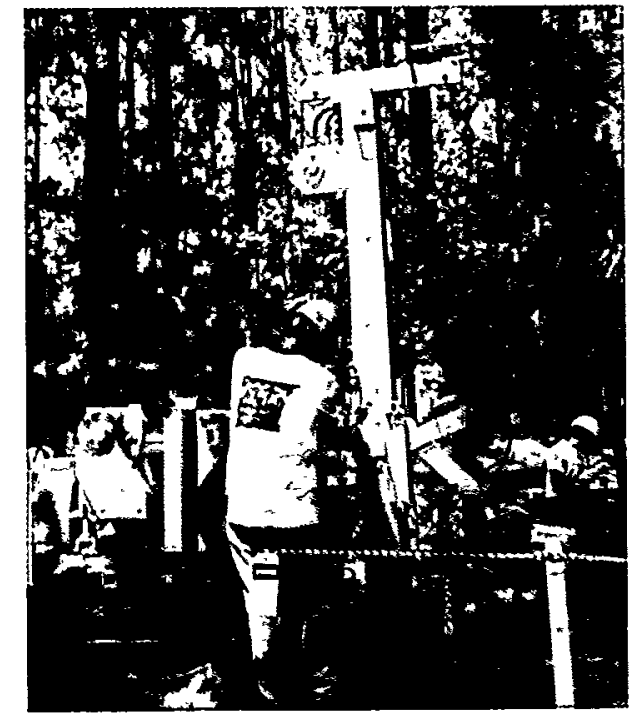

This compact direct-push track-rig helps the project team take samples in small spaces.

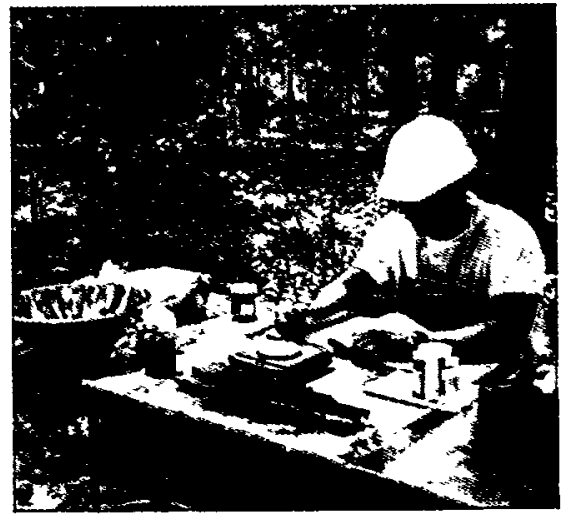

Volatile organic samples are measured in the field.
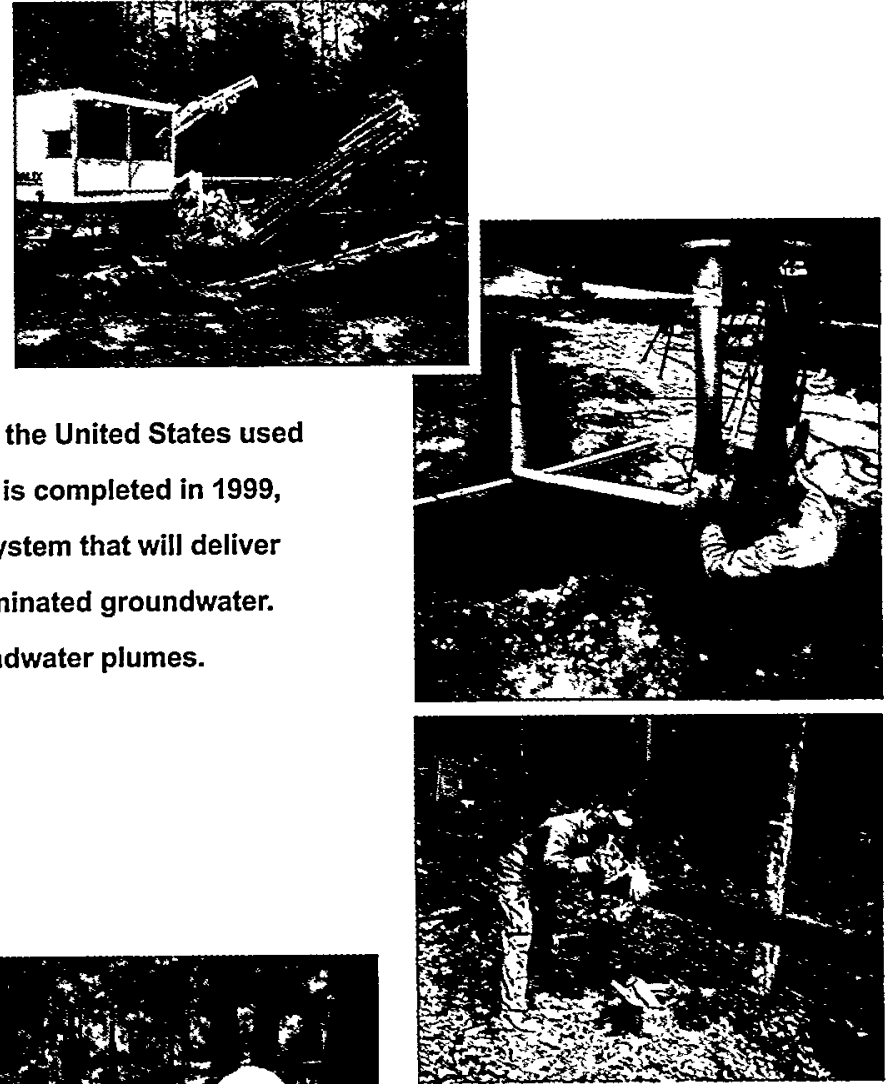

At the NRWDF, horizontal wells and the above ground infrastructure for the bioremediation system were both installed. 
Savannah River Site

Environmental Restoration Division
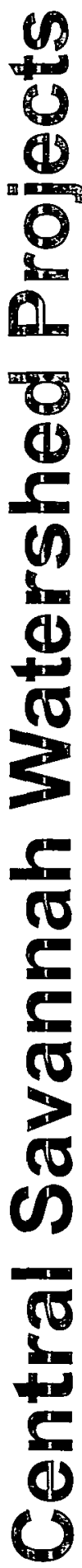

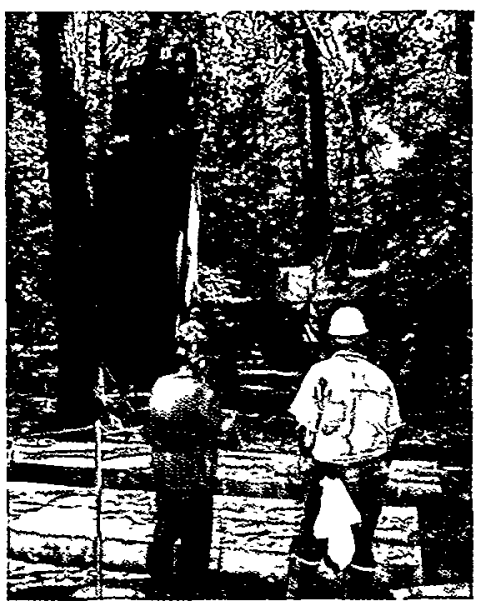

A second 8-foot diameter well was installed for the GeoSiphon cell.

\section{The GeoSiphon cell was modified to enhance remediation.}

The Central Savannah Watershed Project Areas realized major achievements in 1998. The GeoSiphon cell was modified to new levels for remediation success, the team completed a critical tank removal action in the Central Shops Area, and DAsh Basin sampling work began.

The GeoSiphon cell, a passive treatment system, continues to be an important emerging technology at the Savannah River Site. The cell, a large 8-foot diameter well, was installed using the auger and caisson method. The granular cast iron in the well acts as a treatment medium to remediate solventcontaminated groundwater. The first cell was installed in 1997.

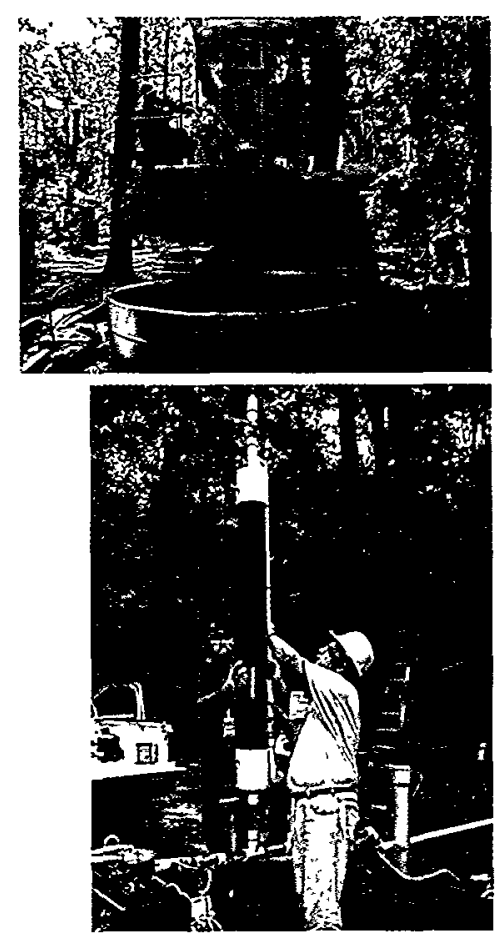

(Above) The auger-caisson method was used to install the cell for the GeoSiphon. (Below) Off-gas collection/discharge chamber maintains siphon action through the GeoSiphon cell. 
In 1998, Phase II testing of the first cell began. The purpose of this testing is to determine acceptable siphon flow rate and the required cell spacing and to demonstrate the technology.

A second cell was installed in September 1998. This cell was placed approximately $\mathbf{5 0}$ feet south of the initial cell. Dual cell testing will begin next year to evaluate the effectiveness of the two cells working in tandem.

Another important FY 98 remediation accomplishment for the Central Savannah Watershed Team was the Ford Building Tank removal action. Located in the Central Shops Area, the Ford Building was used to refurbish reactor heat exchanger units and other processing equipment. From 1964 to 1984, wastewater generated during these operations was piped to the 6,000-gallon underground retention tank and analyzed for radionuclides.

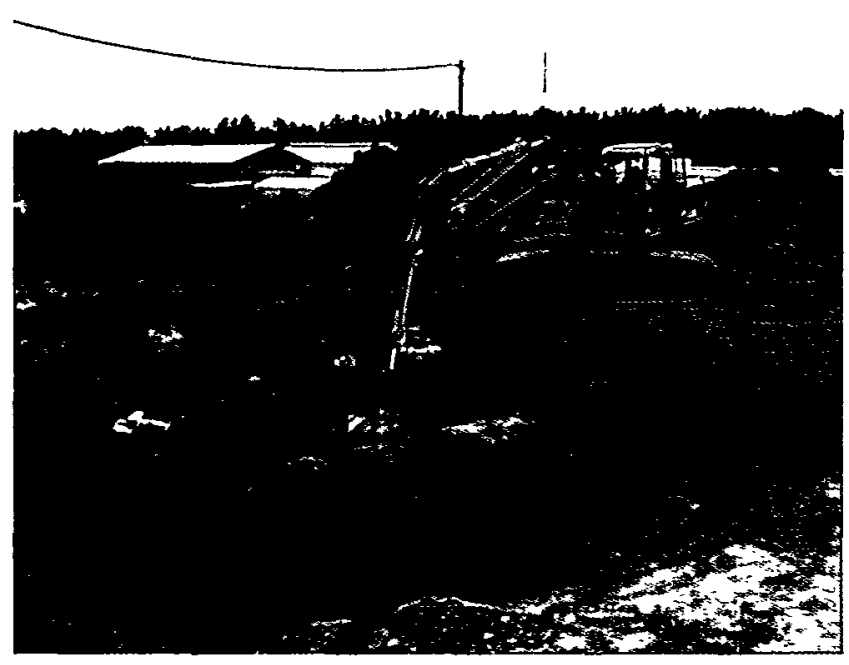

A time-critical removal action was deemed necessary in 1997 when it was discovered that approximately 4,500 gallons of low-level radioactive water and nearly $\mathbf{1 5 0}$ gallons of lowlevel radioactive sludge remained in the tank. The project team completed removal of the tank in September 1998.

The Central Savannah Watershed Projects Team also began sampling at the $488 \mathrm{D}$-Ash Basin (DAB) this year. The basin was put into operation in 1951 and received ash-sluice water from the D-Area powerhouse until 1952. However, after 1952 the basin received dry ash and reject material while ashsluice water was channeled to other basins. The 488-DAB is inactive today and receives no waste materials. Of primary concern is an area of wetlands, approximately 1,250 feet in length and 100 to 300 feet in width, located adjacent to the 488-DAB. This area has been impacted by low $\mathrm{pH}$ runoff and leachate from the area. Low $\mathrm{pH}$ runoff flowing into the wetlands would change the acidity of the water, killing plant life. Other contaminants from the unit that may be found in its leachate are heavy metals, naturally occurring radionuclides, trichloroethylene, and tritium. These all have the potential to damage the wetlands. Full characterization of the basin began ahead of schedule in September 1998.

The Ford Building Tank, located in the Central Shops Area, was successfully removed during the summer of 1998. Extensive radiation worker training and personal protective equipment prevented the spread of contamination during disassembly of the tank.

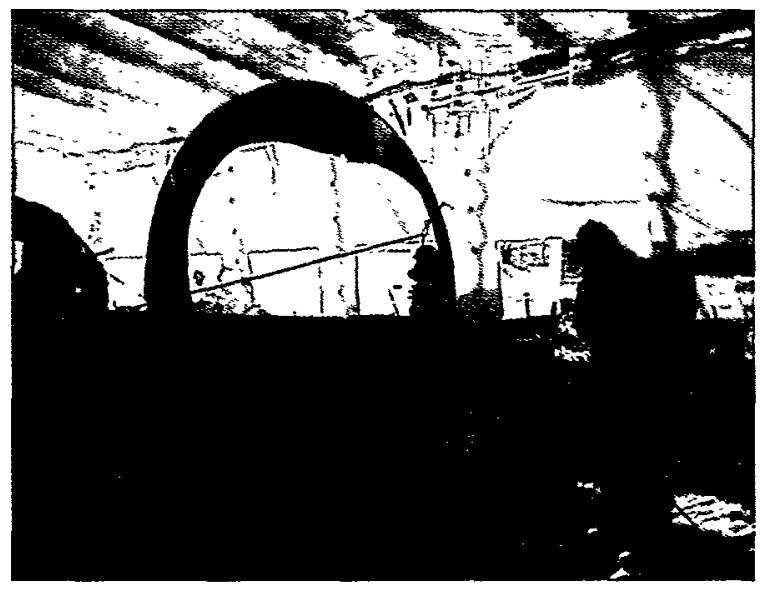


Savannah River Site

Environmental Restoration Division

\section{The Burial Ground Complex (BGC) occupies approximately 195 acres.}

Within the General Separations Projects are the Buriai Ground Cómplex (BGC), the fF and $H$ Groundwater reatment facilifies, and the Old FAArea Seepage Basin (OEASB). These sis.

facilities contain radioactive materials and have some relationship to the chemical "

separations proqess thata produced radioactiveisotopes from reactor targets and spent fuel rods.<smiles></smiles>

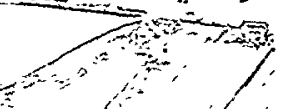

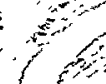

The'BGC occupieśapproximately 194 acres in thécentral section of SRS between Fand $H$ separations areas, The complex is divided into the Low-Level Radioactive Waste Disposal Facility (LLRWDF), the OldRadioactive Waste Burial Ground (ORWBG), and the Mixed

Waste Management Facility (MWMF)

During FY 98, approximately $95 \%$ of the inactive portions of the BGC have been capped Geosynthetic capping over twenty-five acres in LLRWDF was completed in December 1998. Geosynthetic capping is faster, costs less, and provides excellent protection from rainwater infiltration, which could carry contaminated groundwater to the aquifer.

The ORWBG, in the southern 76-acre portion of the BGC, received wastes from 1952 to 1972 . An interim action native soil cover was completed in October 1997 on the ORWBG to minimize infiltration rainwater that

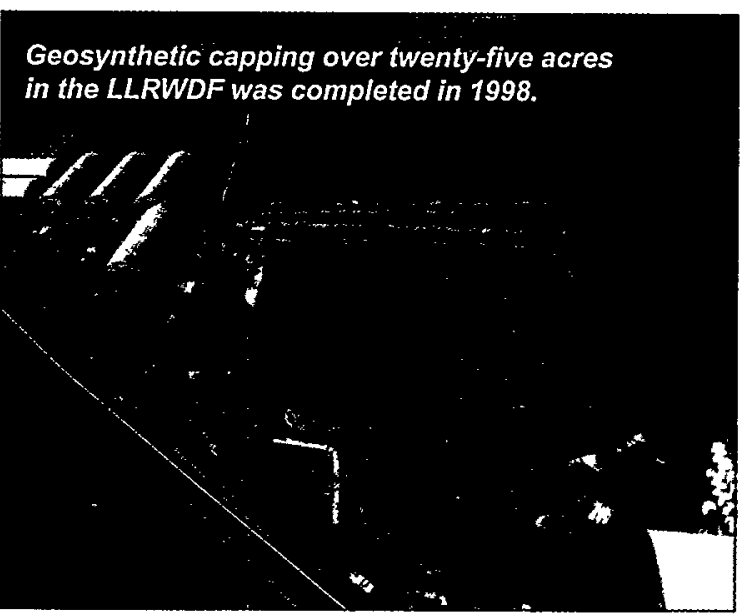


could carry contaminants to the southwest groundwater plume. Also in this complex, more attention has been focused on 22 underground storage tanks that once stored radioactive solvents.

SRS completed liquid sampling and analysis on the solvent tanks and evaluated analytical data to determine the appropriate alternative disposal methods for tank waste. Analytical data on the solvent tank sludge will be provided prior to the evaluation of alternative -disposal methods.

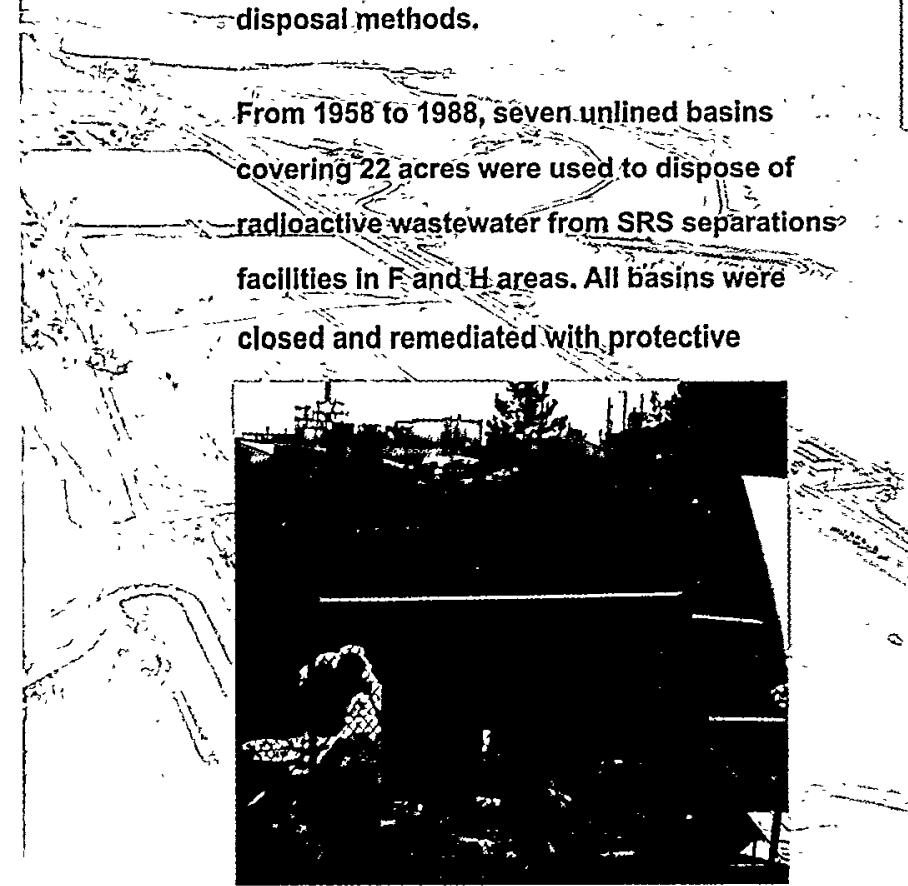

Soil grouting is scheduled to begin at the Old FArea Seepage Basin during 1999.

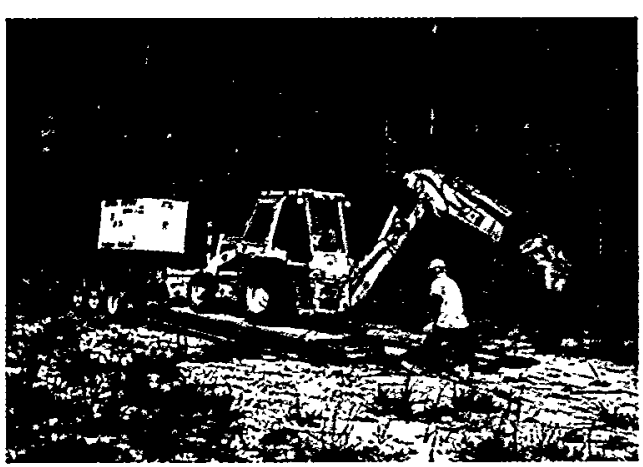

Old F-Area Seepage Basin remedial actions began with vegetation removal.

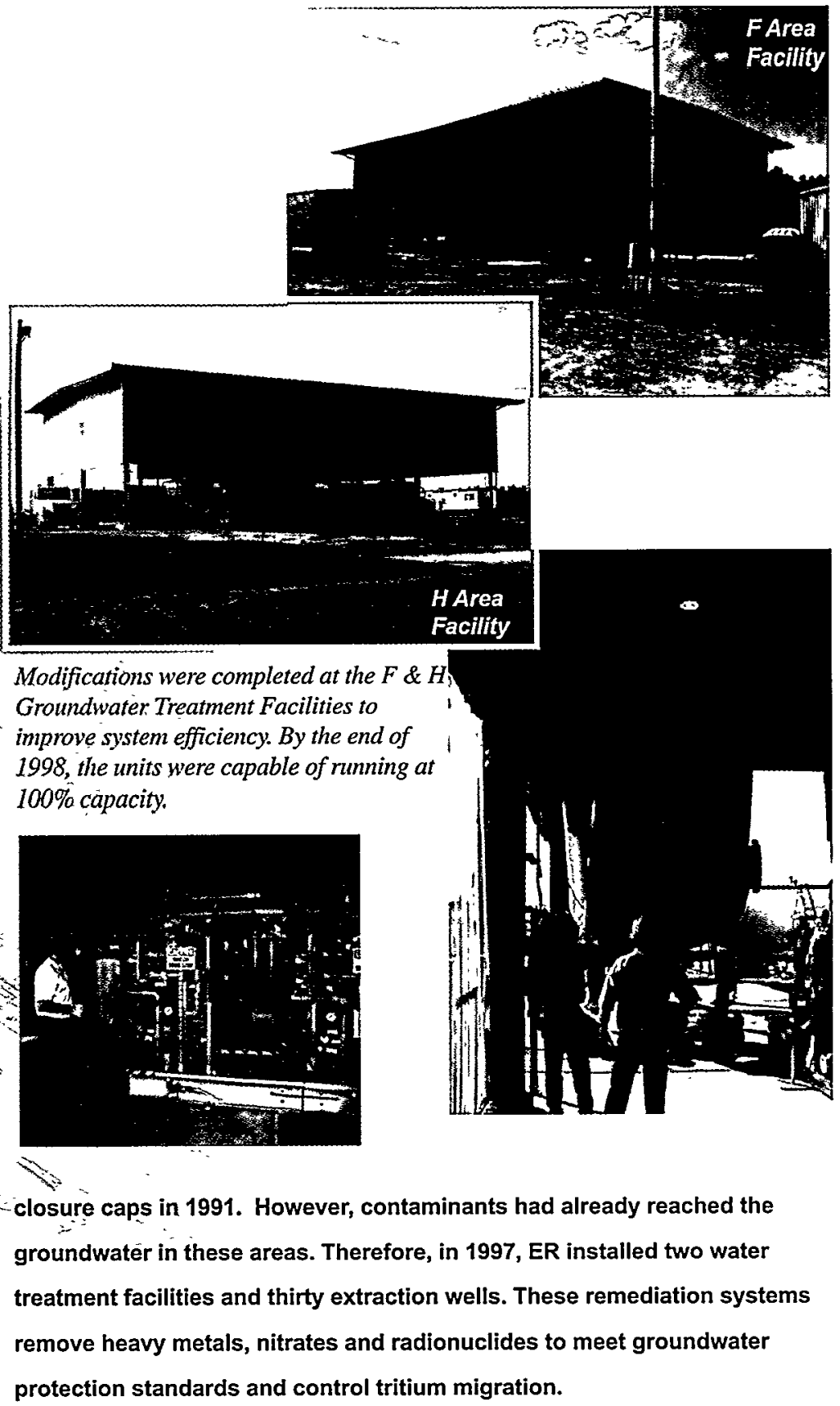

Major components of the systems include reverse-osmosis units, chemical flocculation tanks, ion exchange units, and collection and injection wells. Project engineers have replaced and/or modified many of these components to achieve capacity improvements in removing groundwater contaminants. During 1998, the F and H Area Groundwater Treatment Units began full operation after receiving modifications to enhance system performance. Finally, the soil solidification remedial action at the OFASB was started in September 1998 with a finish date expected in late 1999. 
Savannah River Site

Environmental Restoration Division

\section{Remediation began at the L-Area Oil and Chemical Basin in late August 1998.}

Several significant success stories came from the Reactors Area Project Team in 1998. The project team has delivered a regional groundwater model to help all the reactor areas to focus characterization efforts, completed three removal actions, and accomplished more than $\mathbf{4 0}$ Federal Facility Agreement (FFA) milestones affecting 33 waste sites.

For the first time at SRS, a regional groundwater flow model, which incorporates historical and recent field characterization data, was developed for the K-, R-, P-, and C- reactor areas. The model is being used to guide characterization activities and to perform analysis of the movement of contaminants through groundwater plumes.
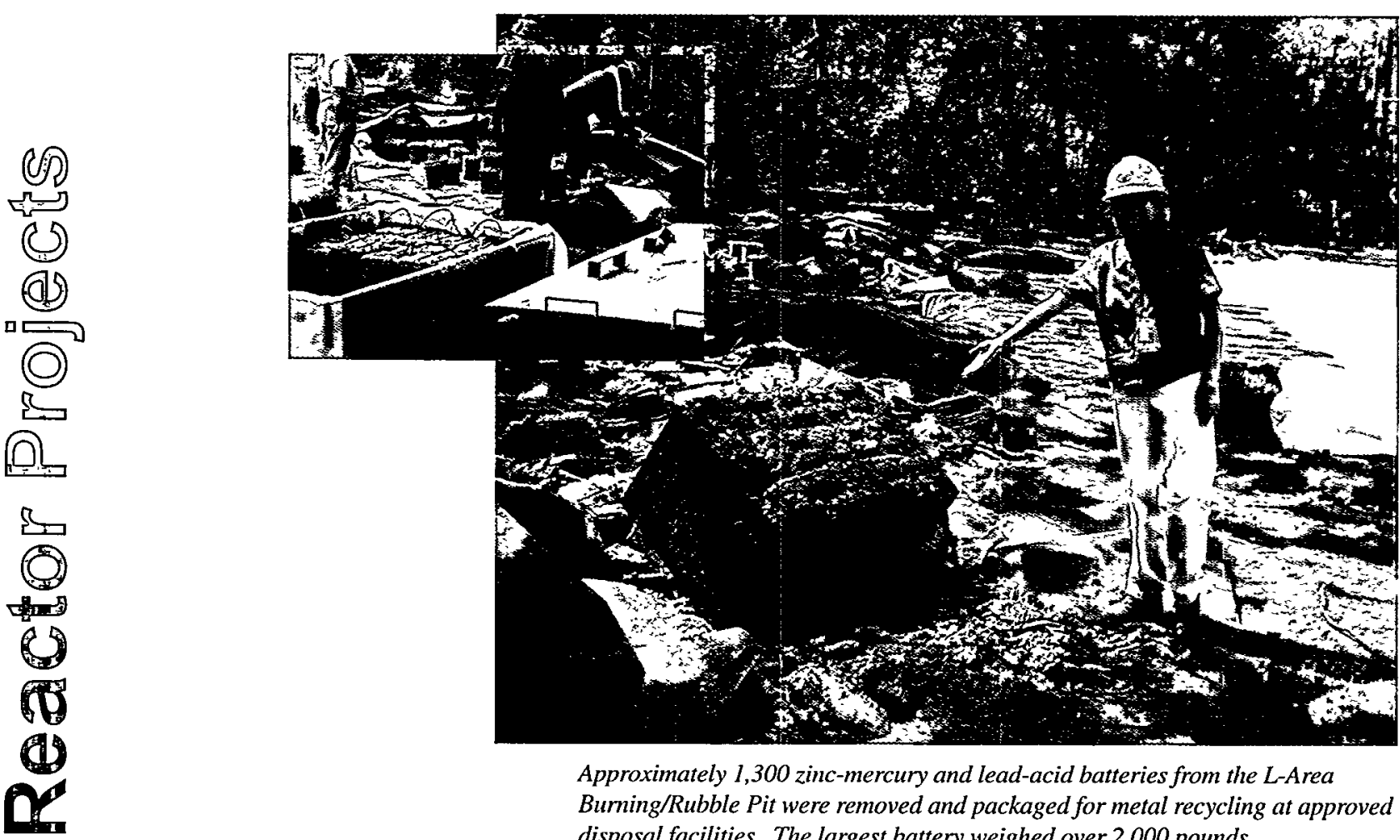

Approximately 1,300 zinc-mercury and lead-acid batteries from the L-Area Burning/Rubble Pit were removed and packaged for metal recycling at approved disposal facilities. The largest battery weighed over 2,000 pounds. 
Another 1998 accomplishment was the removal of approximately 1,300 zinc-mercury and lead-acid batteries from the L-Area Burning/Rubble Pit (131-L). The team discovered the batteries while performing sampling at the waste unit. The packaged batteries will be shipped off site for metals recycling to approved disposal facilities.

A major ER success story in 1998 was the start of remediation work at the L-Area Oil and Chemical Basin (LAOCB) in late August 1998. The basin received radioactive and hazardous wastewater from the early 1960 s to the 1970 s. Filling the entire
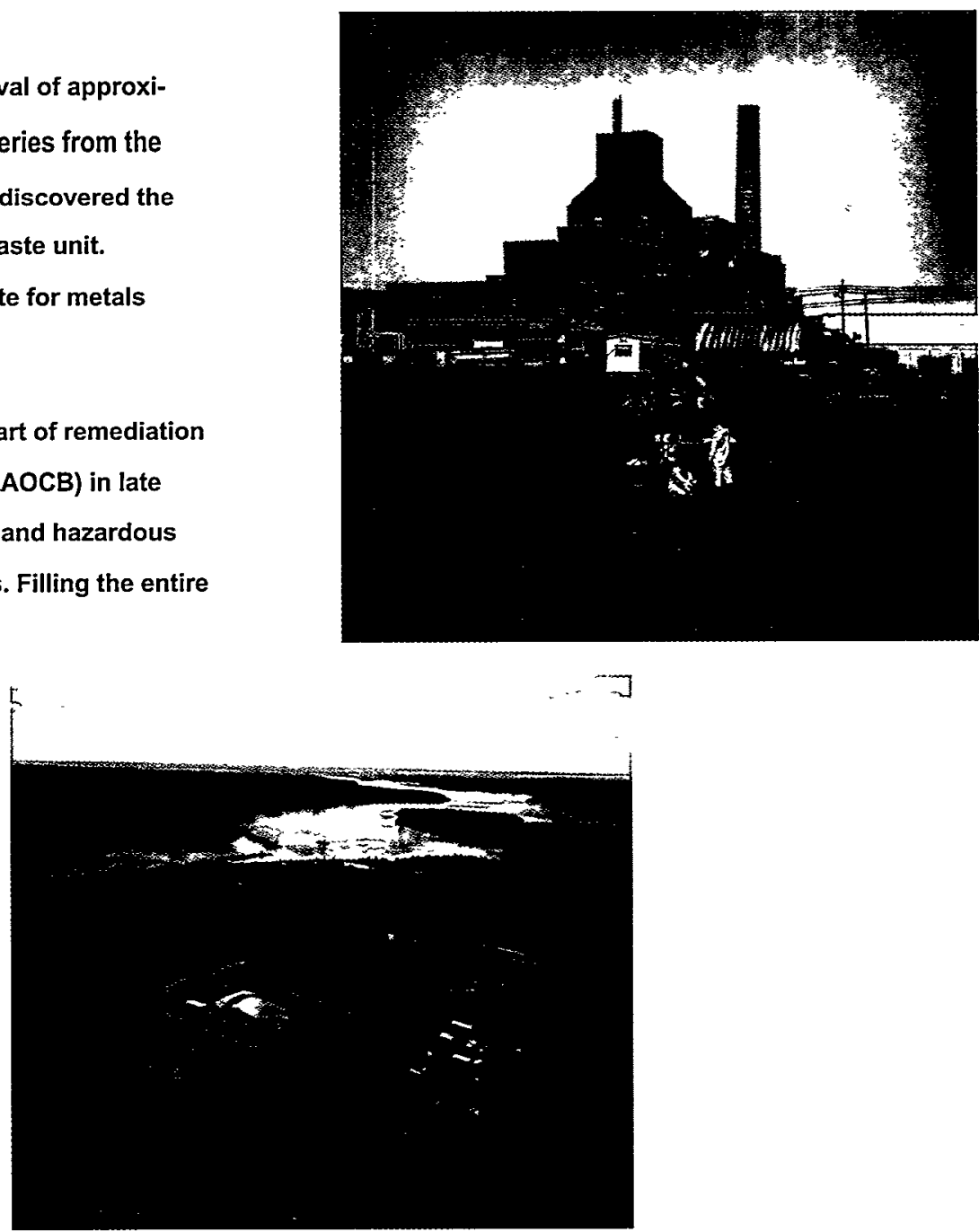

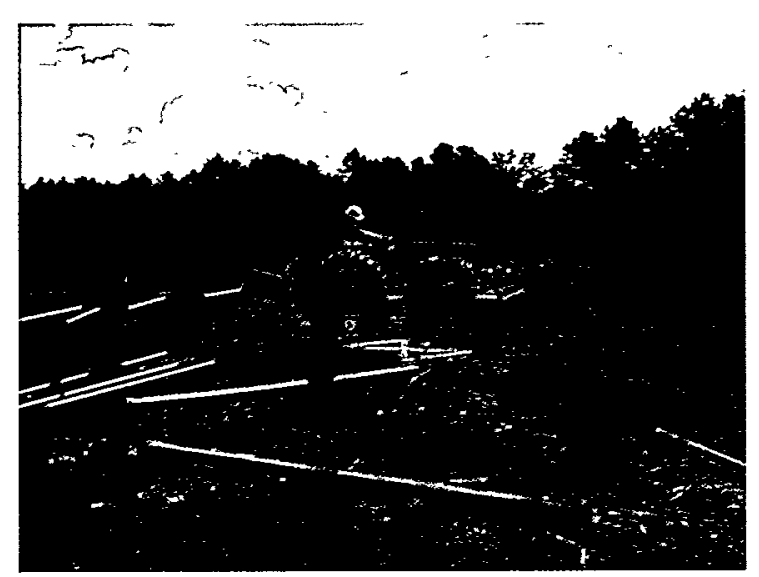

The L-Oil and Chemical Basin remained in use until 1979. Today, the basin is in preparation for remediation and a grout will be used to stabilize the remaining contaminants. basin with grout will safely stabilize the contaminants remaining in the LAOCB. A low permeability soil cover will then be placed over the grouted basin.

Determination of the nature and extent of contamination at the R-Reactor Seepage Basins was completed in 1998 after two years of field characterization. The team used cone penetrometer technology equipment to determine the maximum extent of radioactive (strontium-90) contamination in the groundwater. This technology called a Gamma Probe provided real-time data to speed characterization of the radionuclides in the soil. 


\section{Sharing Information}
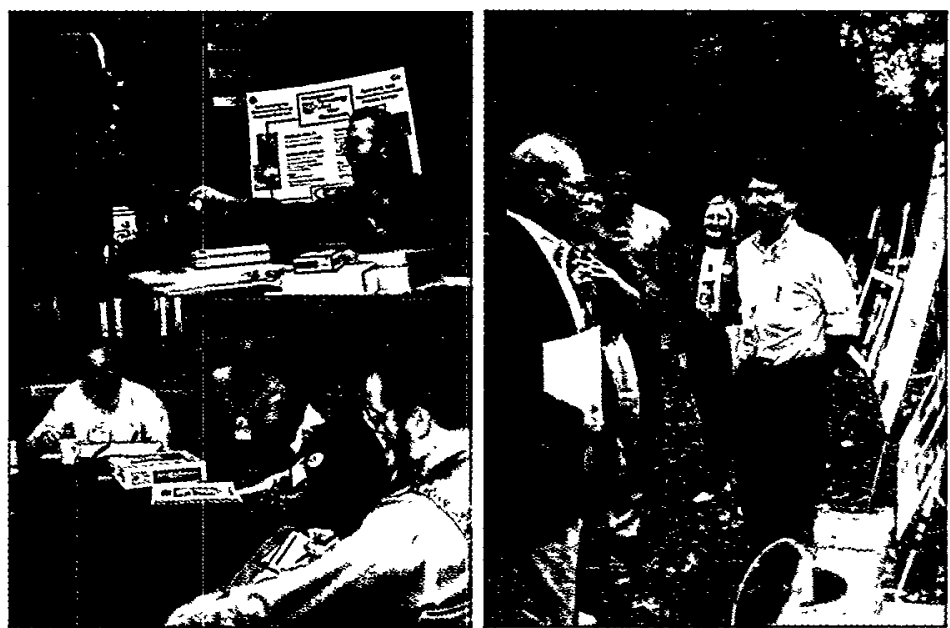

Participants from DOE and other sites around the country attended the Groundwater Technology End User Conference held April 15-16, 1998 in Augusta. A tour of ER sites was also conducted during the activities.

Participants from U.S. Department of Energy (DOE) sites around the country, DOE headquarters in Washington, and Patrick Airforce Base attended the Groundwater Technology End User Conference held April 15-16 in Augusta, Georgia. Hosted by DOE, the conference allowed project and program managers to share information about the specific remediation activities at their sites and to exchange case studies about innovative technologies.

GeoSiphon and Geoflow technologies attracted exceptional interest. Managers touted these technologies because they are both cost effective and passive. Recirculation wells, the solarpowered BaroBall ${ }^{\mathrm{TM}}$, and reinjection technology also stirred interest.

The Augusta Chronicle and WJBF-TV Channel 6 both covered the conference. The media acknowledged SRS as a leader in groundwater cleanup and technology deployment.

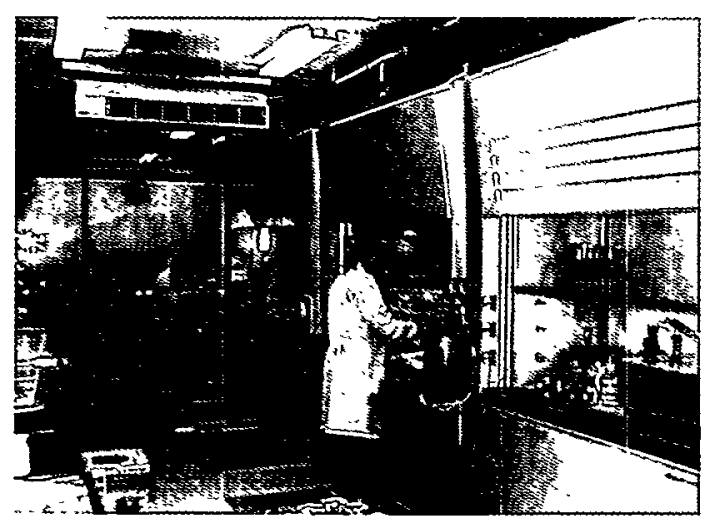

Real-time sampling and lab results significantly increase the characterization process.

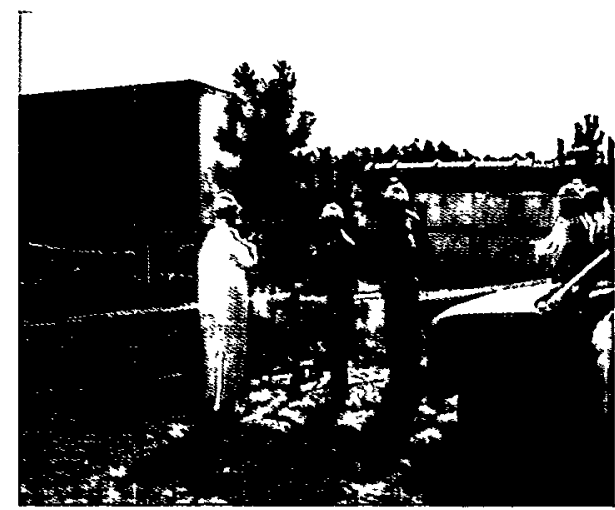

SRS ER supported in situ chemical oxidation remediation at the Kings Bay Naval Base in Georgia during the fall of 1998. 
Through workshops, focus groups, presentations, and town hall meetings, SRS has been keeping its stakeholders informed and involved. Those stakeholders include the public as well as the South Carolina Department of Health and Environmental Control (SCDHEC), and Region 4 of the Environmental Protection Agency (EPA).

During 1998, ER moved one year ahead of schedule to involve the public in weighing remedial action alternatives for the Old Radioactive Waste Burial Ground (ORWBG), a high-risk site. ER further

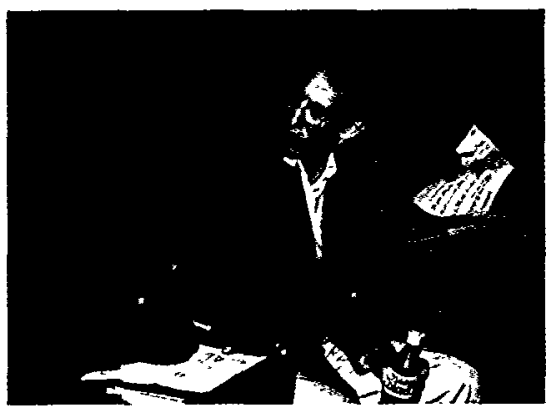

Regular meetings with the Citizen's Advisory Board are a key to improving communications of ER activities. strengthened its relationship with regulators on this project, encouraging both SCDHEC and EPA to join in planning a workshop focused on the ORWBG. Likewise, ER has also sought the recommendations of the public and regulators in evaluating plans for remedial action at the SRL Seepage Basins.

For both these areas, the site's Citizen's Advisory Board (CAB) has played a critical role. Formed in 1994, the CAB is comprised of 25 non-partisan, independent citizens. It has provided guidance in the past to both $E R$ and regulators. For the ORWBG, the CAB is recommending development of a workgroup to scrutinize final remedial action alternatives. In addition,
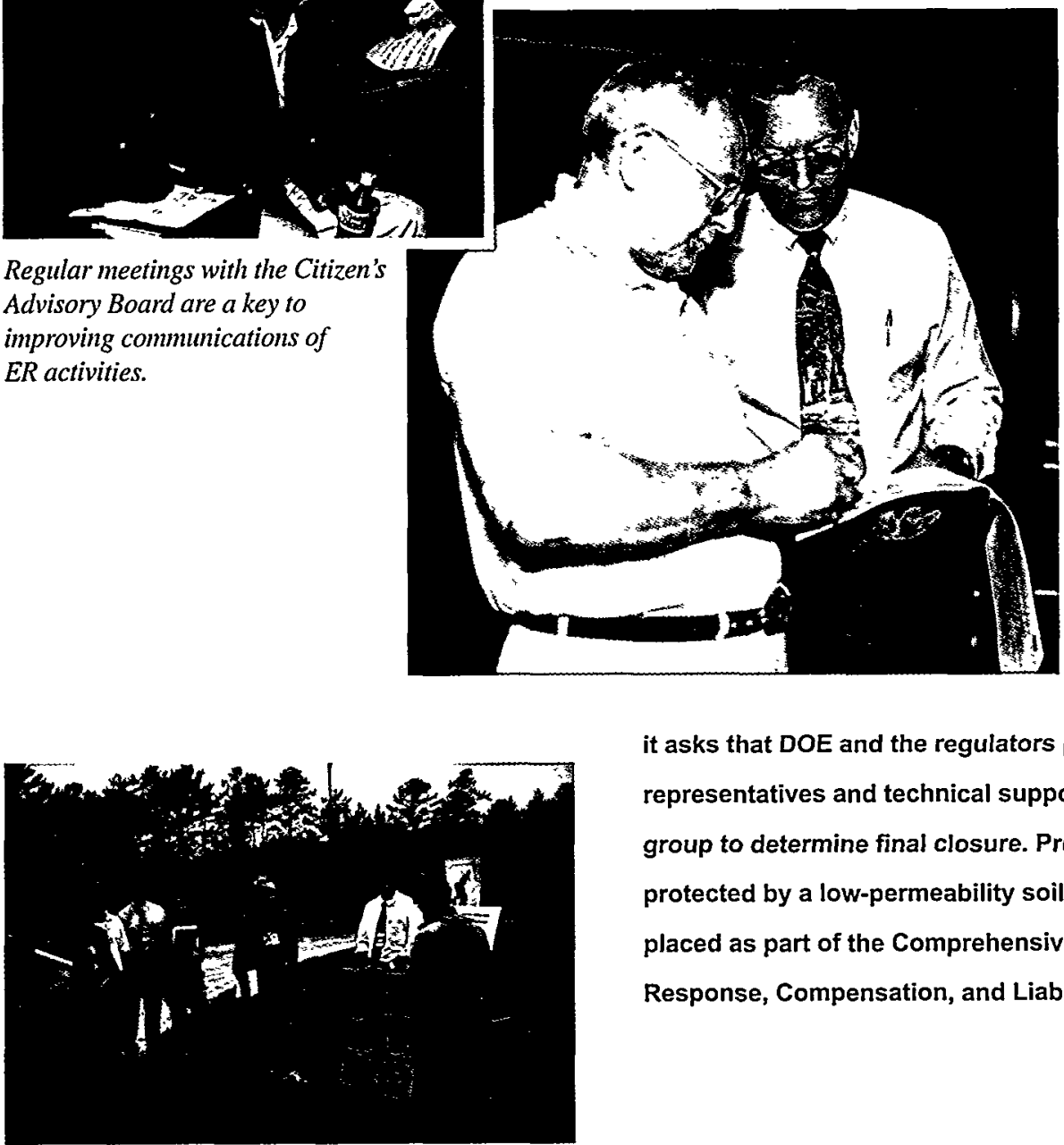

it asks that DOE and the regulators provide dedicated representatives and technical support to the focus group to determine final closure. Presently, the site is protected by a low-permeability soil cover that was placed as part of the Comprehensive Environmental Response, Compensation, and Liability Act.

Tours are provided to show our progress and accomplishments in the field. 


\section{Performance-Based Management 1998}
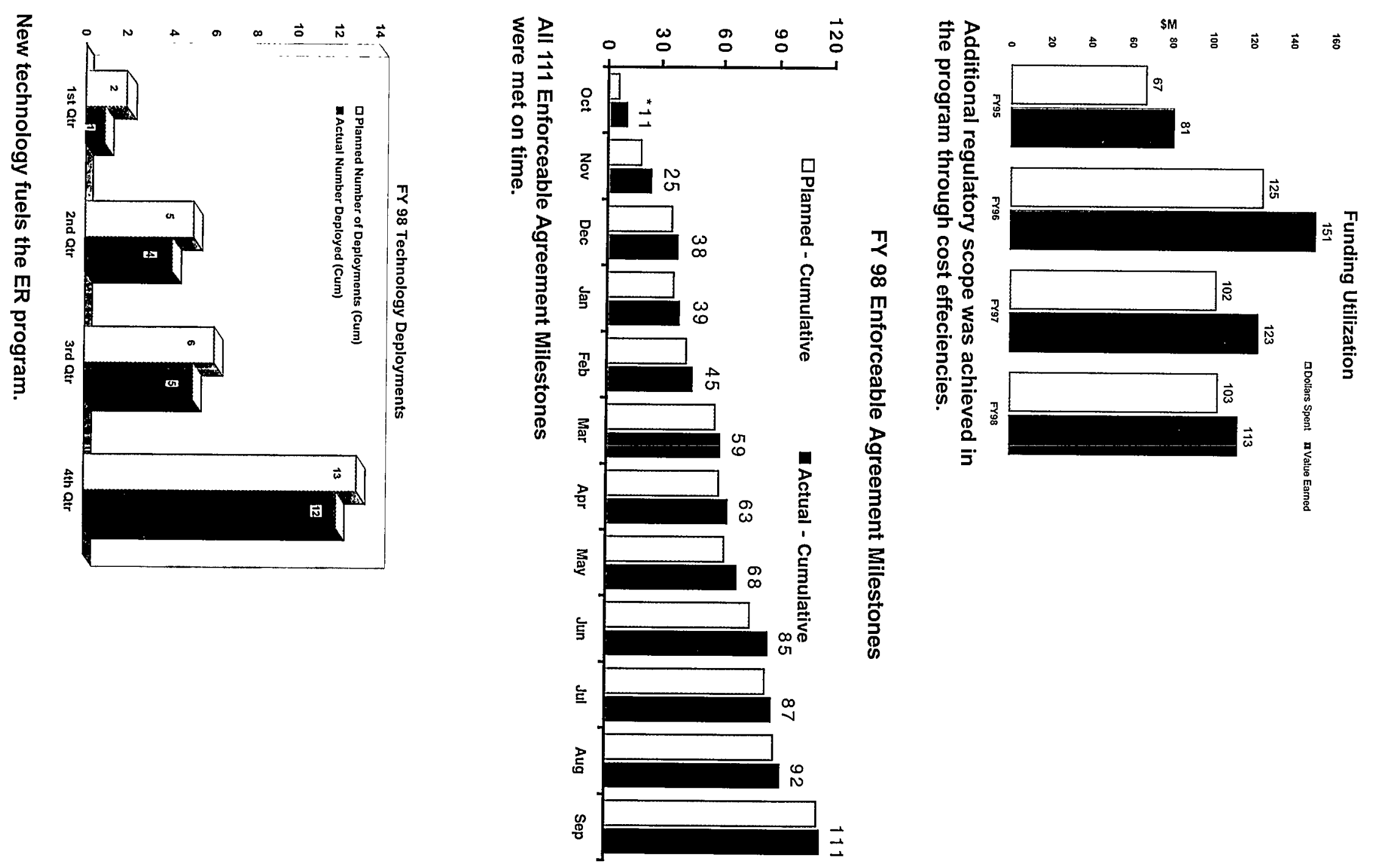


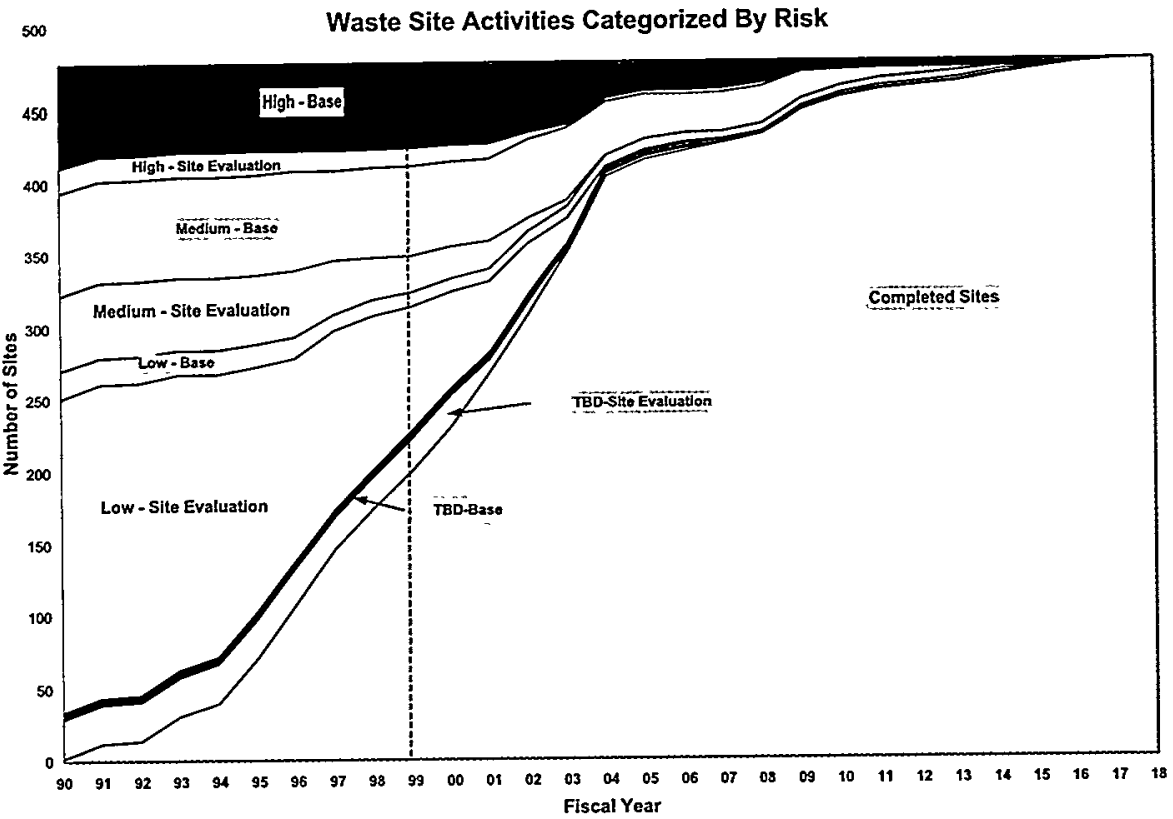

Note: These projections are based on funding levels reflected in the Accelerated Cleanup Plan.

\section{Objective:}

The mission of the SRS ER Program is to remediate waste sites and groundwater units in order to reduce risk to the environment for future land use and to demonstrate capabilities to attract and succeed in new missions.

\section{Goal:}

SRS ER Program goals are to complete characterization and remedy selection for all currently identified waste sites/release areas (including No Further Action sites) and to complete remediation of high risk waste sites (excluding groundwater sites) by 2006 .

\section{Analysis:}

Data reflected above shows projected progress using current funding profile. 
Environmental Restoration expects to achieve many goals in 1999. The Safety Works Campaign will emphasize continued improvements in fieldwork practices. The goal is to surpass the current record of 451 days without a lost time accident.

The division will keep its focus on remediation while continuing to improve operations effectiveness and to employ innovative technology. The division expects to:

- Complete construction of the GeoSynthetic Cap at the Low-Level Radioactive Waste Disposal Facility

- Complete characterization and technology evaluation for remedial action of Solvent Tanks at Old Radioactive Waste Burial Ground

- Start up new Recirculation Wells for groundwater cleanup in the Upper Three Runs Area

- Demonstrate groundwater cleanup at the TNX GeoSiphon Cells

- Begin in situ soil grouting at the L-Area Oil/Chemical Basin and Old F Seepage Basin

- Start Interim Action at the C-Reactor Burning/Rubble Pit using air sparging and soil-vapor extraction units

- Continue operation of F/H Groundwater Units

Environmental Restoration expects to complete all enforceable agreement milestones on or ahead of schedule.

The Environmental Restoration Technology End User Conference in June 1999 will be an opportunity for the program to exchange information with other government sites. 